AL-MARSHAD: JURNAL ASTRONOMI ISLAM DAN ILMU-ILMU BERKAITAN

ISSN 2442-5729 (print) || ISSN 2598-2559 (online), http://jurnal.umsu.ac.id/index.php/almarshad DOI: https://doi.org/10.30596/jam.v4i1.1939

Published June 2018

\title{
Benang Merah Penemu Teori Heliosentris: Kajian Pemikiran Ibn Al-Syāṭir
}

\author{
Siti Nur Halimah \\ Pascasarjana Ilmu Falak UIN Walisongo Semarang \\ Email: schalimah.95@gmail.com
}

\begin{abstract}
Abstrak
Para tokoh astronom Muslim telah memainkan peran yang penting dalam peradaban Islam, salah satunya yaitu dalam perkembangan dan kemajuan astronomi, khususnya ilmu Falak. Beberapa dari mereka telah menyumbangkan banyak hal dalam rangka memajukan astronomi; baik dari pemikiran, buku, maupun alat pendukung untuk mempermudah astronomi dan Falak. Teori-teori para astronom Muslim ini digunakan sebagai panduan dan masih dipelajari hingga saat ini. Salah satu tokoh paling menonjol dari para astronom Muslim pada abad keempat belas adalah Ibn Al-Shāțir. Ibn Al-Syāṭir adalah pelopor pembentukan teori heliosentris yang memecahkan teori Geosentris Ptolemy. Namun demikian, ternyata sejarah lebih akrab dengan Nicholas Copernicus sebagai penemu awal teori heliosentris. Berdasarkan hal itu, penulis ingin membahas tentang pemikiran Ibnu Al-Syāțir dan kontribusinya terhadap kemajuan astronomi. Penulis menemukan bahwa Ibn Al-Shātir adalah seorang tokoh yang mengkritik teori geosentris Ptolemeus, ia memetakan gerakan planet-planet di ruang angkasa sampai teori heliosentris didirikan, sekitar 2 abad sebelum Nicolas Copernicus. Ibnu Al-Syāṭir berhasil menulis beberapa buku seperti Nihāyat al-Sūl Fi Tashih alUsul serta menciptakan alat pendukung dalam astronomi dan Falak; astrolabe dan sundial (jam matahari).
\end{abstract}

Artikel Info

Received:

20 Februari 2018

Revised:

17 Maret 2018

Accepted:

21 Mei 2018

Keyword: Ibn Al-Syātir, ilmu falak, teori heliosentris.

\section{A. Pendahuluan}

Ribuan tahun yang lalu, ketika nenek moyang kita melihat ke angkasa, mereka mulai bertanya dalam hati tentang apa yang mereka llihat di sana. Dengan kerangka berpikir yang masih mempercayai tahayul, mereka melihat angkasa sebagai sesuatu yang menakjubkan. Hal-hal yang terjadi di sana, seperti kemunculan komet, bagi mereka merupakan isyarat akan terjadinya malapetaka, seperti kematian, kehancuran, wabah penyakit, kekeringan atau banjir. Para pemuka 
agama terdidik yang menuntun peradaban awal, mulai mempelajari kejadian-kejadian di angkasa dengan sungguh-sungguh, mencari tanda-tanda yang dapat digunakan untuk meramalkan kejadian baik atau buruk sehingga berkembanglah astrologi (ramalan bintang) ${ }^{1}$. Walaupun para pemuka agama tersebut mempelajari angkasa untuk alasan yang salah ditinjau dari kacamata ilmu pengetahuan, pengamatan mereka sudah meletakkan dasar-dasar astronomi. ${ }^{2}$ Astronomi merupakan salah satu ilmu penting bagi orang Islam dalam beberapa alasan keagamaan: astronomi membantu nafigasi untuk tujuan-tujuan perdagangan serta perjalanan, astronomi juga penting untuk menentukan kalender Kamariyah, menentukan waktu salat dan arah Kakbah di Makkah serta

1 Astrologi adalah suatu praktik kepercayaan berasal dari Babilonia kuno berdasarkan horoskop yang digunakan untuk menentukan nasib/untung seseorang menurut kedudukan dan gerak benda langit. Walaupun astrologi memegang peranan penting pada awal pengambangan astronomi, namun kini astrologi tidak berkaitan dengan astronomi. Susiknan Azhari, Ensiklopedi Hisab Rukyat,

${ }^{2}$ Robbin Kerrod, Astronomi, The Ivy Press Limited, 1999. Diterjemahkan oleh Syamaun Peusangan, (Jakarta: Erlangga, 2015), h. 6. mengetahui waktu gerhana baik

Matahari atau Bulan.

Pada perkembangannya, para astronom Muslim tidak hanya mengasimilasi ilmu pengetahuan dari Yunani, bahkan mereka dapat mengembangkannya lebih jauh seperti halnya Abu 'Abbās Ahmad Ibn Muḥammad Ibn Kașīr al-Fargāni (alFargāni) membuat jadwal apogee dan perigee, Abu Ja'far Muhammad Ibn Mūsa al-Khawarizmi (al-Khawarizmi) penggagas aljabar dan penemu angka 0 (nol), Abu Raiḥān al-Birūni (al-Birūni), 'Alā' ad-Dīn Abu al-ḥasan 'Ali Ibn Ibrahīm Ibn Muḥammad al-Anșārī adDimasyq̄̄ (Ibn al-Syāțir), dan lain sebagainya.

Ilmu astronomi mengenal tiga teori tentang pergerakan benda langit yaitu: pertama, teori egosentris ${ }^{3}$; kedua, teori geosentris ${ }^{4}$. Kemudian sejumlah

3 Teori yang beranggapan bahwa manusia merupakan pusat dari peredaran benda-benda langit.

4 Geosentris adalah teori yang mengatakan bahwa bumi merupakan pusat tatasurya. Berasal dari kata geo (Bumi) dan pusat. Pemahaman ini menolak pemahaman yang menyatakan manusia sebagai pusat. Teori ini mempunyai pengaruh sangat besar waktu itu. Masyarakat yunani mempercayai bahwa Bumi adalah pusat tata surya, teori ini cukup lama hingga pada abad pertengahan (abad XII s/d XV) yaitu orang- 
astronom Muslim mencoba mengkritik pemikiran Ptolomeus tentang teori geosentrisnya, sehingga muncullah teori ketiga, teori heliosentris 5 . Teori heliosentris merupakan teori terakhir yang dipercayai sampai saat ini dan tidak ada yang membantahnya. Permasalahannya adalah dalam sejarahsejarah astronomi yang beredar, peradaban Barat seringkali mengklaim Nicolaus Copernicus (1473-1543 M) sebagai pencetus teori heliosentris dalam tata surya. Sejarawan astronomi bernama Edward S. Kennedy, seorang Profesor matematika di Universitas Amerika di Beirut menemukan fakta

orang di Eropa khususnya dibarat yang sangat mendukung Aristoteles, apasaja yang diaktakan Aristoteles dianggap mutlak benar. Beberapa abad kemudian, mucul seorang pemikir dari Mesir-Yunani bernama Ptolomeus (127-151 M) yang melakukan perubahan yang cukup signifikan, hal ini dijadikan refrensi oleh para ahli astronomi hingga pada zaman Renaissance. Menurut Ptolomeus : Matahari, Bulan, dan Planet-lanet yang beredar mengelilingi Bumi dengan suatu system yang rumit. Yang isinya menggambarkan bahwa Bumi menjadi pusat peredaran Bulan, Planet-planet lain, diantaranya Matahari, dengan urutan sebagai berikut : Bulan, Merkurius, Venus, Matahari, Mars, Yupiter, Saturnus, dan sebagainya. Slamet Hambali, Pengantar Ilmu Falak, Banyuwangi : Bismillah Publisher. hlm. 179-182.

5 Heliosentris adalah teori yang mengatakan bahwa matahari merupakan pusat dari tatasurya. bahwa ide matematika antara buku Copernicus yang berjudul De Revolutionibus memiliki kesamaan dengan sebuah buku yang pernah ditulis seratus tahun sebelumnya oleh ilmuwan Muslim Arab, Ibn al-Syātị (1304-1375 M). ${ }^{6}$ Hal ini menjadi hipotesa awal dalam tertutupnya sejarah Ibn al-Syātir pada abad ke empat belas yang sejatinya merupakan tokoh yang berjasa dalam pembentukan teori ini. Para akademisi lebih mengenal Nicolaus Copernicus sebagai "Bapak Heliosentris". Astronomi hanya mengenal teori yang dibangun Kepler dan Copernicus setelah runtuh batas-batas Bumi teori tanpa mempertimbangkan teori Ibn alSyāṭir yang justru merupakan teori pertama yang memetakan gerakan planet-planet di angkasa; sebuah teori yang diyakini milik dunia modern sebagai Kepler dan Copernicus. ${ }^{7}$

Menggunakan metode kajian kepustakaan, penulis akan menelisik bagaimana cara Ibn al-Syāțir dalam

nsiklopedia-

${ }^{6}$ http://www.republika.co.id/berita/e islam/khazanah/09/07/15/62257-ibnu-alshatir-sang-penemu-jam-astrolab

7 Wahyu Setiawan, Geneologi Tradisi Ilmiah Astronomi Islam (Studi Historis Perkembangan Astronomi Muslim Pada Abad Pertengahan), Jurnal STAIN Jurai Siwo Metro 
menemukan teori heliosentrisnya. Sehingga kemudian pembaca dapat memahami kesalahpahaman yang selama ini menganggap bahwa Nicolaus Copernicus adalah penemu awal dari teori heliosentris, sedangkan tahun hidup keduanya bahkan terpaut ratusan tahun jaraknya.

\section{B. Pembahasan}

\section{Riwayat Hidup Ibn al-Syāțir}

'Alā' ad-Dīn Abu al-ḥasan 'Ali Ibn Ibrahīm Ibn Muḥammad al-Anșārī ad-Dimasyqī, lebih dikenal dengan sebutan Ibn al-Syāțir, lahir di Damaskus pada bulan Maret tahun $1306 \mathrm{H}^{8}$. Ia adalah seorang muwaqqit (pengatur jam) sehingga ia bertanggung jawab untuk waktu yang tepat untuk melaksanakan salat, selain itu ia juga menjadi serta ketua para muadzin di masjid Jami'al-Umawī, Damaskus. ${ }^{9}$

8 Dalam literatur yang lain disebutkan bahwa Ibn al-Syāțir lahir pada tahun 1305 M. Charles Coulston Gillipspie, Dictionary of Scientific Biography Vol 12, New York, 1961, hlm. 357. Lihat juga pada 'Abd al-Qādir Ibn Muhammad an-Nu'aimi ad-Dimasyqi, Ad-Dārus fì at-Tārikh alMadāris, Maktabah aś-Ṡaqāfah adDīniyyah, 1988. Ibn al-Syāțir lahir di Damaskus pada 15 Sya'ban $705 \mathrm{H}$.

9 George Sarton, Science and Learning in the Fourteenth Century Vol III, (New York: Robert E. Krieger Publishing Company, 1975), h. 1524.
Ayah Ibn al-Syātịir meninggal saat Ibn al-Syāțir berusia 6 tahun. Kemudian ia tumbuh besar bersama kakeknya, ialah yang mengajari Ibn alSyāṭir tentang kesenian memahat gading. Pada umurnya yang ke sepuluh, Ibn al-Syāṭir pergi ke Kairo dan Alexandria untuk belajar astonomi. Kemudian ia terkenal sebagai ahli astronomi, ahli matematika serta insinyur. Ibn al-Syāṭir wafat di Damaskus pada tahun $1375 \mathrm{M}$.

\section{Kajian Pemikiran Ibn al-Syāṭir}

Dari pengalamannya di dunia astronomi, Ibn al-Syāṭir menulis risalah yang berjudul Nihāyat al-Sūl Fi Tashih al-Ușūl merombak habis teori geosentris Ptolomeus, kendati belum beranjak dari teori geosentris, tapi secara matematis Ibn al-Syātị memperkenalkan adanya epicycle (system lingkaran dalam lingkaran). Ibn al-Syāṭir mencoba menjelaskan bagaimana gerak merkurius jika bumi menjadi pusat alam semesta-nya, dan Merkurius bergerak mengitari Bumi.

Ia dikenal dengan teori planetnya dan pencipta orsinil beberapa instrument astronomi yang dipakainya untuk pengamatan maupun komputasi. Dalam teori planetnya ia mengikuti 
teori al-Thusi yang menemukan "Thusi Couple" dan menyempurnakannya. Berdasarkan teorinya tersebut ia mengoreksi teori Ptolomeus tentang gerakan planet. Dari hasil pengamatannya ia menemukan bahwa untuk dapat mengamati planet-planet luar - Mirikh (Mars), Mustary (Jupiter), dan Juhal (Saturnus)- secara sempurna Bumi tidak mungkin lagi dapat dianggap sebagai pusat pergerakan sirkular planet (geosentris), dia mengajukan teori yang menjadikan matahari sebagai pusat pergerakan sirkular planet (heliosentris). Dengan modelnya ini Ibnu syatir dapat memberikan solusi yang memuaskan yang selama ini dianggap pelik untuk dua benda orbital dalam tatasurya, Atorrois (Merkurius) dan Bumi. Hasil yang dicapai oleh Ibn al-Syāțir sama peresis dengan model yang dibuat oleh Copernicus, dan tak dapat diragukan lagi bahwa Copernicus pernah mempelajari karya-karya Ibn al-Syāțir. ${ }^{10}$ Secara garis besar, para astronom Muslim dapat diklasifikasikan menjadi dua mazhab: pertama, mazhab

${ }^{10}$ Slamet Hambali, Pengantar Ilmu Falak, (Yogyakarta: Bismillah Publisher, 2012), h. 266-267. yang berorientasi matematis di bagian timur dunia Muslim; dan kedua, mazhab yang berorientasi filosofis dengan basis di wilayah barat kekuasaan dunia Muslim. Para astronom dari tradisi timur mengadopsi strategi reformasi matematika dalam upaya untuk memecahkan masalah teoritis dari model Ptolomeus. Dua alat matematika yang berguna dan sangat berpengaruh saat itu diciptakan oleh astronom abad ke tiga belas, yaitu atṬūsi dan al-Urdi. Alat pertama, yang dikenal dalam keilmuan modern sebagai Thusi Couple, yang menghasilkan osilasi linier sebagai hasil dari kombinasi dari dua gerakan melingkar seragam. Alat ini digunakan dalam berbagai cara oleh banyak astronom, termasuk astronom Nicolaus Copernicus Polandia. Alat kedua adalah Urdi Lemma, yaitu alat matematika serbaguna yang diciptakan oleh al-Urdi dan digunakan para penerusnya. ${ }^{11}$

Cara untuk menerapkan Lemma ini yaitu dengan model planet-planet atas, misalnya, al-Urdi membalik arah

\footnotetext{
${ }^{11}$ Sebagaimana dikutip oleh Wahyu Setiawan dalam Astronomy, dalam http://www. oxfordislamicstudies.com/article/book/isla $\mathrm{m}$,
} 
gerak dan membagi eksentrisitas dari model Ptolomeus. Dengan demikian mampu menghasilkan gerak seragam sekitar pusat geometri dari bola, sementara pada saat yang sama mereproduksi gerakan seragam di sekitar pusat equant Ptolomeus. Untuk menghasilkan representasi optimal secara fisik dan matematis, astronom lain mengkombinasikan kedua alat tersebut dan menemukan alat tambahan dari penemuan mereka sendiri.

$$
\text { Model yang paling }
$$

komprehensif dan sukses diperkenalkan pada abad ke empat belas adalah model Ibn al-Syāțir: modelnya untuk semua planet menggunakan kombinasi gerakan melingkar sempurna dimana setiap lingkaran berputar seragam di sekitar pusat, hal ini dituangkan Ibn al-Syāțir dalam ridalah kajiannya Nihāyat al-Sūl Fi Tashih al-Ușūl. Ibn al-Syāṭir juga mampu memecahkan masalah jarak planet dan untuk menyediakan data yang lebih akurat untuk observasi astronomis. Ibn al-Syāțir adalah ilmuwan yang pertama kali memetakan pergerakan planet di luar angkasa, teori yang diyakini dunia modern sebagai milik Kepler dan Copernicus.
Periode Ibn al-Syātịi inilah yang dilewatkan dalam sejarah astronomi dunia. Setelah Ptolomeus, orang hanya mengenal Copernicus (1473-1543 M). Dalam diagram astronomisnya, Ibn alSyāṭir menjelaskan tentang pergerakan planet Merkurius. Temuannya saat itu dianggap sebagai sikses representasi gerakan planet di atata surya. ${ }^{12}$ Model geometris Ibn al-Syāṭir merupakan karya pertama yang benar-benar unggul daripada model Ptolemaic karena modelnya ini lebih baik sesuai dengan pengamatan empiris. Dalam membuat model barunya tersebut, Ibnu al-Shatir melakukan pengujian dengan melakukan pengamatan empiris.

Tidak seperti astronom sebelumnya, Ibn al-Syāțir umumnya tidak keberatan terhadap falsafah astronomi Ptolemeic, tetapi ia ingin menguji seberapa jauh teori Ptolemy dengan pengamatan empirisnya. Ia menguji model Ptolemaic, dan jika ada yang tidak cocok dengan pengamatannya, maka ia akan merumuskan sendiri medel non-

12 Islam Dan Warisan Ilmu Astronomi (Ilmu Falak) dalam http://lajnah falakiyah lamongan.wordpress.com/2011/02/10/islam -dan-warisan-ilmu-astronomi-ilmu-falak/ diakses pada 6 Oktober 2017, pukul 00.45. 
Ptolemaic pada bagian yang tidak cocok dengan pengamatannya.

Ibn al-Syāțir memulai pemikiran astronomi planetnya dengan menyiapkan sebuah zij, sebuah buku pedoman astronomi dengan tabel-tabel. Pemikirannya ini yang secara keras berdasarkan pada teori planet Ptolemaic ternyata tidak bertahan. Pada risalahnya yang selanjutnya dengan judul Ta'līq al-Arsyād (Commentson Observations), ia menggambarkan pengamatanpengamatan dan prosedur-prosedur yang dengan hal tersebut ia membangun model planetary barunya dan memperoleh parameter yang baru. Tidak ketahui adanya salinan risalah ini yang masih eksis dari sumber-sumber manuskrip. Kemudian, pada Nihāyat alSūl Fi Tashih al-Ușūl (A Final Inquiry Concerning the Rectification of planetary Theory). Disini, Ibn al-Syāttir menyajikan alasan dibalik model planet barunya. Pemikirannya ini bisa bertahan. Akhirnya, Az-Zij al-Jadīd milik Ibn al-Syāṭir masih ada dalam beberapa salinan manuskrip, berisi sebuah kumpulan table-tabel planet berdasarkan pada teori dan parameternya yang baru. Pokok dari teori planet Ibn al-Syāțir secara nyata adalah penghapusan model equant Ptolemaic dengan epicycles kedua sebagai penggantinya. ${ }^{13}$

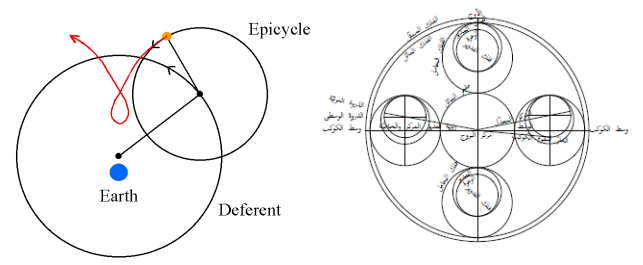

Gambar 1. Model Orbit Ptolomeus dan Ibn al-Syāțir

Dalam teori geosentris Ptolomeus dikenal istilah deferent (epicycle), dan equant. Dalam tahap selanjutnya Ibn al-Syāṭir menekankan pengamatan equant sebagai asumsi bahwa yang menjadi pusat orbit bukanlah Bumi, tetapi titik equant. Konsep inilah yang kemudian menjadi hipotesa awal Ibnu al-Syāṭir, bahwa benda-benda langit itu bukanlah mengelilingi Bumi, tetapi mengelilingi titik equant yang pada tahap selanjutnya tergantikan oleh Matahari.

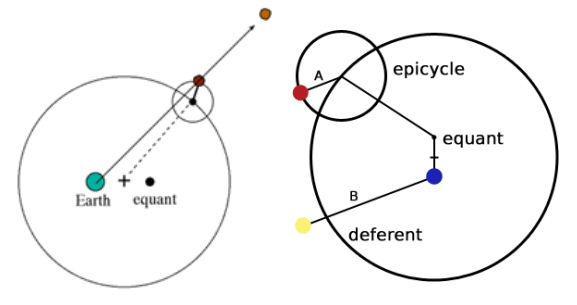

13 Thomas Hockey, The Biographical Astronomers, (New York: Springer, 2007), h. 569-570. 
Gambar 2. Orbit pada Bumi dan Orbit pada titik Equant

Pengamatannya yang akurat membuat Ibn al-Syāṭir yakin menghapus epicycle dalam model matahari Ptolomeic. Sejumlah model Ibn al-Syātị direproduksi satu setengah abad kemudian oleh Nicolaus Copernicus dalam melakukan reformasi astronomi pada tradisi ilmiah Barat. Kitab Nihāyat al-Sūl Fi Tashih al-Ușūl merupakan risalah astronomi Ibn alSyātir yang paling penting. Dalam kitab itu, secara drastis Ibn al-Syātị mereformasi model matahari, bulan, dan planet Ptolemic. Dengan memperkenalkan sendiri model nonPtolemic yang menghapuskan epicycle pada model matahari, yang menghapuskan eksentrik dan equant. Dengan memperkenalkan epicycle ekstra pada model planet melalui model Tusi-couple, dan yang menghilangkan semua eksentrik/eccentric, epicycle dan equant di model bulan. ${ }^{14}$

Selain pemikiraanya mengenai teori heliosentris, Ibn al-Syāṭir juga

14 George Saliba, A History of Arabic Astronomy: Planetary Theories During the Golden Age of Islam berhasil menulis beberapa karya tntang astronomi diantaranya yaitu ${ }^{15}$ :

1. Nihāyat al-Gāyāt fì A'māl alFalakiyyāt (The Final Work on Astronomical Operations)

2. Ta'līq al-Arsyād (Commentson Observations). Pada risalah ini Ibn al-Syāṭir menggambarkan pengamatan-pengamatan dan prosedur-prosedur yang dengan hal tersebut ia membangun model planetary barunya dan memperoleh parameter yang baru.

3. Nihāyat al-Sūl Fi Tashih al-Ușūl (A Final Inquiry Concerning the Rectification of planetary Theory). Disini, Ibn al-Syāțir menyajikan alasan dibalik model planetary barunya.

4. Zīj Ibn Syātitr. Yaitu Zij yang datang berasal dari rantai sejarah antara Zij al-Battāni dan Ibn Yūnus (az-Zīj al-Hākimi al-Kabìr) dan Zij at-țūsi. ${ }^{16}$

5. Raṣd Ibn Syāțir

6. Nuzhat as-Syams fì al-'Amal bi alRub'al-Jami

15 Ilias Fernini, A Bibiography of Scholars in Medieval Islam 150-1000 A.H (750-1600 A.D), (Abu Dhabi: Cultural Foundation, 1998), h. 381.

${ }^{16}$ Kamus al-Islāam, Kairo, 1976, h 13. 
7. An-Naf al-Am fì al-'Amal bi alRub'at-Tām

8. Mukhtașar fi al- 'Amal bi al-Isțirlāb

9. Iddah Mugayyab fi al-'Amal bi alRub'al-Mujayyab

10. Az-Zij al-Jadīd ${ }^{17}$

Pada masanya, Ibn al-Syāții juga berhasil menciptakan alat-alat pembantu dalam ilmu astronomi dan ilmu falak, diantaranya yaitu:

1) Astrolabe

Kata astrolabe berasal dari bahasa Yunani yang terdiri dari kata astro dan labio. Astro berarti bintang dan labio berarti pengukran jarak. Sementara itu dalam istilah ilmu falak, astrolabe adalah berkakas kuno yang biasa digunakan untuk mengukur kedudukan benda langit pada bola langit. ${ }^{18}$

2) Sundial

Menurut catatan sejarah, sundial atau jam matahari merupakan jam tertua dalam peradaban manusia. Jam ini telah dikenal sejak tahun 3500 SM.

17 Susiknan Azhari, Ensiklopedi Hisab Rukyat, (Jogjakarta: Pustaka Pelajar, 2008), h. 86.

18 Susiknan Azhari, Ensiklopedi Hisab Rukyat, (Jogjakarta: Pustaka Pelajar, 2008), h. 36.
Pembuatan sundial di dunia Islam dilakukan oleh Ibn al-Syātịr. Sundial yang dibuat oleh Ibn alSyāțir merupakan sundial kuno yang yang didasarkan pada garis jam lurus. Ibn al-Syātịir membagi waktu dalam sehari dengan 12 jam, pada musim dingin waktu pendek, sedangkan pada musim panas waktu lebih panjang. Sundial Ibn al-Syāṭir merupakan polar-axis sundial tertua yang masih tetap eksis hingga saat ini.

3) Kompas

David A. King mengatakan Ibn al-Syāṭir juga menemukan kompas, sebuah perangkat pengatur waktu yang menggabungkan jam matahari dan kompas magnetis pada awal abad ke-14 M.

4) Instrumen Universal

Ibn al-Syāṭir menjelaskan instrumen astronomi lainnya yang ia disebut sebagai "instrumen universal". Penemuan Ibn al-Syāțir ini kemudian dikembangkan seorang astronom dan rekayawasan legendaris di era kekhalifahan Turki Usmani, Taq̄ī ad-Dīn. Instrumen itu digunakan di 
observatorium ad-Dīn Istanbul

$1577-1580 \mathrm{M}$

\section{Penutup}

Ibn al-Syātị lahir di Damaskus pada 15 Sya'ban $1306 \mathrm{M}$ dan wafat di Damaskus pula pada tahun 1375 M. Ia belajar astronomi di Kairo dan Alexandria. Pemikiran Ibn al-Syātị sebagai sumbangsihnya terhadap keilmuan astronomi yaitu tentang teori heliosentris. Jauh sebelum Copernicus lahir, Ibn al-Syātị telah berhasil menemukan bahwa Bumi bukanlah pusat dari tatasurya melainkan Matahari. Hal ini diketahuinya dari pengamatan empiris dengan menggabungkan alat at-Ṭūsi dan alUrdi sehingga diketahui pergerakan benda-benda langit. Selain pemikiran, Ibn al-Syāṭir juga menelurkan karyakarya dalam beberapa risalah, diantaranya yang paling penting yaitu Nihāyat al-Sūl Fi Tashih al-Ușūl yang memuat dasar teori tentang pemikiran heliosentrisnya. Beberapa kontribusi Ibn al-Syātịir dalam bidang teknik yaitu ia berhasil menciptakan astrolabe, sundial, kompas dan instrument universal.

\section{Daftar Pustaka}

Azhari, Susiknan. (2008) Ensiklopedi Hisab Rukyat Jogjakarta: Pustaka Pelajar.

Dimasyqi, 'Abd al-Qādir Ibn Muhammad an-Nu'aimi. (1988) Ad-Dārus fì at-Tārikh al-Madāris. Maktabah aśŚaqāfah ad-Dīniyyah.

Fernini, Ilias. (1998). A Bibiography of Scholars in Medieval Islam 150-1000 A.H (750-1600 A.D), Abu Dhabi: Cultural Foundation.

Gillipspie, Charles Coulston. (1961). Dictionary of Scientific Biography Vol 12, New York.

Hambali, Slamet. (tt). Pengantar Ilmu Falak. Banyuwangi : Bismillah Publisher.

Hockey, Thomas. (2007) The Biographical Astronomers. New York: Springer.

Kerrod, Robbin. (1990). Astonomi, The Ivy Press Limited, Jakarta: Erlangga.

Saliba, George (1987). "Theory and Observation in Islamic Astronomy: The Work of Ibn al- Shātir of Damascus." Journal for the History of Astronomy 18: 3543. (Reprinted in Saliba, $A$ History of Arabic Astronomy: Planetary Theories during the Golden Age of Islam. New 
York: New York University Press.

Sarton, George. (1975). Science and Learning in the Fourteenth Century Vol III, New York: Robert E. Krieger Publishing Company.

Setiawan, Wahyu, Geneologi Tradisi Ilmiah Astronomi Islam (Studi Historis Perkembangan Astronomi Muslim Pada Abad Pertengahan), Jurnal STAIN Jurai Siwo Metro.

http://www.

oxfordislamicstudies.com/articl e/book/islam,

http://lajnah falakiyah lamongan.wordpress.com/2011 /02/10/islam-dan-warisanilmu-astronomi-ilmu-falak/ diakses pada 6 Oktober 2017, pukul 00.45.

http://www.republika.co.id/berita/ensi klopediaislam/khazanah/09/07/15/622 57- ibnu-al-shatir-sangpenemu-jam-astrolab 